\title{
Methods of Legal Regulation of Digital Relations in the Field of Industrial Safety and Labor Protection
}

\author{
Natalya Danilina ${ }^{1, *}$ Elena Chertakova ${ }^{2}$
}

\author{
${ }^{1}$ Department of Management of Industrial and Environmental Safety, Togliatti State University, Samara 445020, Russian \\ Federation \\ ${ }^{2}$ Department of Business and Labor Law, Togliatti State University, Samara 445020, Russian Federation \\ *Corresponding author. Email: Danilina@tltsu.ru
}

\begin{abstract}
The article analyses the problems of the modern system of legal regulation of digital relations in the field of industrial safety and labor protection in the Russian Federation and on a global level. Procedures regulatory digital interactions, such as regulatory authorities among themselves and their interaction with the employer in the part of inspections, the issuance of regulations of attraction to administrative responsibility. Developed proposals for the implementation of complex of measures on improvement of mechanisms of digital interaction between employer and regulatory services in the field of industrial safety and labor protection. Developed program of training of specialists on labor protection and industrial safety on the legal regulation of digital relations.
\end{abstract}

Keywords: Digital relationships, legal regulation, digital relations, technological supervision, individual protection.

\section{INTRODUCTION}

The national project "Digital economy" is determined by the deadlines of 1 October 2018 to 31 December 2024. The project is aimed at solving tasks on improvement of living standards, improving the quality of manufactured goods and services through the use of modern digital technologies. The program should be based on legal regulation, development of education, infrastructure, support projects and studies, information of national security.

Today, the system of economic, social and cultural relations is the application of digital technologies [1]. Among the five basic directions of development of digital economy in the country - legal regulation, personnel and their training, formation of research competences and technological bases, information infrastructure and security. Approval of the directions of development of the digital economy, goals, objectives, plans is a strategic management level. The tactical level involves managing the implementation of plans and tasks and projects.

\section{MATERIALS AND METHODS OF THE STUDY}

In the Russian Federation today is virtually nonexistent the system of legal regulation of digital relations in the field of industrial safety and labor protection [2]. The number of automated government services and functions in the field of controlling, supervising and permitting activities, the implementation of which is authorized by the Federal service for ecological, technological and nuclear supervision and Federal service for labor and employment is not enough.

In the reporting of information on law enforcement Supervisory, the annual analysis of statistical data published on the websites of the Federal service for ecological, technological and nuclear supervision and Federal service for labor and employment, shows the lack of knowledge of the legal law responsible in the field of industrial safety and labor protection, as these areas are areas of the hard normative behaviour, and the number of violations of requirements of industrial safety and labor protection is growing every year [3].

All the results of scheduled and unscheduled inspections of organizations, their regulators lie outside the scope of the digital economy, as are the old-fashioned way, by checking the relevant documents, and filling checklists.

The authors analysed the websites of relevant regulatory bodies - the Federal service for ecological, technological and nuclear supervision and Federal service for labor and employment on the basis of elaborated criteria from the point of view of specialists on industrial safety and labor protection. The websites of the regulatory bodies are the tools, allowing to solve tasks in the field of industrial safety and labor protection [4].

The analysis of sites was carried out by the developed system of criteria: 
1. The style (design) of the site.

2. Design site structure (information availability, number of nesting levels).

3. The navigation offered by the site: menus, sliders, buttons - their location and design.

4. The presence and number of banners on the website.

5. Visual perception (convenience, simplicity and understanding by the user).

6. The definition of the main goals that allows you to solve the website in the relevant fields.

7. Specific problems solved with the help of this website.

8. The availability of the required functionality in the relevant fields.

9. The presence of feedback with the user.

10. Regular changes in the information provided (relevance of information, Supplement the regulatory framework documents).

11. The presence of a review of current enforcement practice in the respective fields.

12. The loading speed of the website by the user.
13. The availability of contacts for the various forms of feedback.

14. The presence of a forum of professional community in their respective areas.

15. The presence of feedback on the website.

16. The availability of the passing self-test for organizations.

17. The presence of state services in electronic form

18. The possibility of receiving complaints and appeals in electronic form.

19. The mobile version of the website.

We developed a grading scale for each criterion with scores from 1 to 5 points, defining three levels of evaluation:

0-1 score (0-19) - a low level;

2-3 points (38-57) - average level;

4-5 points (76-95) - high level [4].

The results of the analysis sites are presented in table 1 that follows [5].

Table 1 Results of analysis of the websites of the Federal service for ecological, technological and nuclear supervision and Federal service for labor and employment

\begin{tabular}{|c|c|c|}
\hline Evaluation criteria & $\begin{array}{l}\text { The website of the Federal service for } \\
\text { ecological, technological and nuclear } \\
\text { supervision (number of points) } \\
\text { http://www.gosnadzor.ru/ }\end{array}$ & $\begin{array}{c}\text { The website of the Federal service for } \\
\text { labor and employment } \\
\text { (number of points) } \\
\text { https://www.rostrud.ru/ }\end{array}$ \\
\hline The style (design) of the website & 5 & 5 \\
\hline $\begin{array}{c}\text { Design site structure (information } \\
\text { availability, number of nesting } \\
\text { levels) }\end{array}$ & 4 (peragus levels of nesting) & 5 \\
\hline $\begin{array}{l}\text { The navigation offered by the site: } \\
\text { menus, sliders, buttons - their } \\
\text { location and design }\end{array}$ & 4 (complicated navigation) & 5 \\
\hline $\begin{array}{l}\text { The presence and number of banners } \\
\text { on the website }\end{array}$ & 5 (no foreign banners) & 5 (no foreign banners) \\
\hline $\begin{array}{c}\text { Visual perception (convenience, } \\
\text { simplicity and understanding by the } \\
\text { user) }\end{array}$ & 4 (lots of information) & 5 \\
\hline $\begin{array}{l}\text { The definition of the main goals that } \\
\text { allows you to solve the website in the } \\
\text { relevant fields }\end{array}$ & 5 (mission and values of Rostekhnadzor) & $\begin{array}{c}5 \text { (Declaration of goals and tasks of the } \\
\text { Federal service for labor and } \\
\text { employment) }\end{array}$ \\
\hline $\begin{array}{l}\text { Specific problems solved with the } \\
\text { help of this website }\end{array}$ & 5 (policy statement RTN) & $\begin{array}{c}5 \text { (Declaration of goals and tasks of the } \\
\text { Federal service for labor and } \\
\text { employment) }\end{array}$ \\
\hline $\begin{array}{l}\text { The availability of the required } \\
\text { functionality in the relevant fields }\end{array}$ & 5 & 5 \\
\hline $\begin{array}{c}\text { The presence of feedback with the } \\
\text { user }\end{array}$ & 4 (difficult access) & 5 \\
\hline $\begin{array}{l}\text { Regular changes in the information } \\
\text { provided (relevance of information, } \\
\text { Supplement the regulatory } \\
\text { framework documents) }\end{array}$ & $\begin{array}{l}5 \text { (report on law enforcement compliance and } \\
\text { enforcement activities by the Federal service } \\
\text { for ecological, technological and nuclear } \\
\text { supervision in the implementation of Federal }\end{array}$ & $\begin{array}{l}4 \text { (reporting information on the } \\
\text { implementation of state supervision over } \\
\text { compliance with labor legislation and } \\
\text { other normative legal acts containing } \\
\text { norms of labor law, and supervision in the }\end{array}$ \\
\hline
\end{tabular}




\begin{tabular}{|c|c|c|}
\hline & $\begin{array}{l}\text { state supervision in the field of industrial safety } \\
\text { for the first } 9 \text { months of 2019) }\end{array}$ & $\begin{array}{l}\text { sphere of social protection of the } \\
\text { population in } 2018 \text {, according to inspecial } \\
\text { of subjects of Federation, the latest } \\
\text { figures for 2016) }\end{array}$ \\
\hline $\begin{array}{l}\text { The presence of a review of current } \\
\text { enforcement practice in the } \\
\text { respective areas }\end{array}$ & 1 & $\begin{array}{l}1 \text { (monitoring of law enforcement } \\
\text { practice with minimal information) }\end{array}$ \\
\hline $\begin{array}{l}\text { The loading speed of the website by } \\
\text { the user }\end{array}$ & 5 (2-3 seconds) & 5 (2-3 seconds) \\
\hline $\begin{array}{l}\text { The availability of contacts for } \\
\text { different forms of feedback }\end{array}$ & 5 & 5 \\
\hline $\begin{array}{l}\text { The presence of a forum of } \\
\text { professional community in the } \\
\text { relevant fields }\end{array}$ & 0 & 0 \\
\hline The presence of reviews on this site & $\begin{array}{l}4 \text { (questioning the applicants on the provision } \\
\text { of public services - unclaimed info) }\end{array}$ & $\begin{array}{c}4 \text { (survey of individuals who submitted } \\
\text { the appeal online on the satisfaction of } \\
\text { performed actions) }\end{array}$ \\
\hline $\begin{array}{l}\text { The availability of the passing self- } \\
\text { test for organizations }\end{array}$ & e & $\begin{array}{c}5 \text { (E-labor inspector allows you to pre-test } \\
\text { or self-test compliance in labor law) }\end{array}$ \\
\hline $\begin{array}{l}\text { The presence of state services in } \\
\text { electronic form }\end{array}$ & $\begin{array}{c}5 \text { (electronic access to public services through } \\
\text { the Single portal of state and municipal } \\
\text { services/functions) }\end{array}$ & 4 (online inspection) \\
\hline $\begin{array}{c}\text { The possibility of receiving } \\
\text { complaints and appeals in electronic } \\
\text { form }\end{array}$ & $\begin{array}{c}5 \text { (e-form to receive complaints against } \\
\text { decisions and actions (inaction) of } \\
\text { Rostechnadzor and its representatives in the } \\
\text { provision of public services) }\end{array}$ & $\begin{array}{l}5 \text { (treatment of citizens/ } \\
\text { to appeal) }\end{array}$ \\
\hline The mobile version of the site & 5 & 0 \\
\hline $\begin{array}{l}\text { The availability of scheduled and } \\
\text { unscheduled inspections only in } \\
\text { digital format }\end{array}$ & 0 & 0 \\
\hline TOTAL & 76 & 78 \\
\hline
\end{tabular}

Thus, the sites of the Federal service for ecological, technological and nuclear supervision and Federal service for labor and employment as we developed the criteria received a high rating [6], but have their weaknesses:

- No forum professional community in the field of industrial safety and labor protection, which could occur an exchange of views and experience of specialists not only in a mode "question-answer" on the part of Supervisory authorities;

- The lack of review of current enforcement practice in the respective areas, that relevant necessary information explaining the main violations and the corresponding sanctions in the field of industrial safety and labor protection;

- The inability to undergo self-assessment for organizations on the website of the Federal service for ecological, technological and nuclear supervision, which would give the opportunity to avoid corresponding penalties for industrial safety, to prevent accidents and fatal injuries;
- No mobile version of the website of the Federal service for labor and employment in the modern digital economy, although the information presented herein are relevant for the employer and employee, and sometimes requires a quick application;

- And finally, the most important is the inability of passing scheduled and unscheduled inspections of organizations regulatory authorities only in digital format because there is no legal regulation of this process.

\section{DIGITAL ECONOMY EXPERIENCE}

Exploring the world experience in the implementation of the digital economy in the field of industrial safety and labor protection we note the following global achievements, which could take on arms of the Russian Federation [7].

For example, in the automatic issuance of the product, i.e. in the production and installation of machines was the first such countries as Italy and the United 
Kingdom. Data from the study by Grand View Research suggests that "the global market for industrial vending machines was estimated at 2.07 billion US dollars in 2018, and is expected to increase during the forecast period until 2025 will account for $8.9 \% "$. The company Manufactures Vending Box vending machines designed for the issuance to the employee of personal protective equipment, and the latest models are equipped with a receiver of bills. This gives you the opportunity to provide individual protection for employees of other organizations who come to the company, for example, installers, fitters, testers. PPE purchased by employees themselves without the involvement of the necessary staff informed [8].

Today, this company Vending Box works in St. Petersburg. It produces not only the devices themselves, but also system information management products issuing and monitoring use of PPE. Products are vending boxes and connecting them to the network software. Vending machines installed at the enterprise for issue of PPE to employees by e-read passes and passwords, provide an opportunity to reduce the consumption of the means of individual protection by 20 $\%$. The main problem of application of the automated systems for issue of PPE lies in the plane of legal regulation, as the order of the health Ministry No. 290 dated 1 June 2009 requires fixing the issue of PPE painting employee in a personal card account of the issue of PPE, and enforcement agencies when the inspection is strictly monitored for its presence.

When a legal decision of the question of implementation of software in conjunction with vending boxes we get the following advantages:

- Control over the flow of goods maximum;

- A simplified procedure for the recovery of stocks of PPE;

- Complete accuracy of the information;

- Personal liability of the employee for PPE received;

- Automated delivery of personal protective equipment for cleaning and washing;

- Increased productivity of employees by reducing the time for issuance of PPE;

- The possibility of integration into automated enterprise management system, storing the data on their own servers;

- Tracking and monitoring of inventory to prevent administrative violations;

- Keeping only electronic records on the state of the PPE as a means of analysis for effective inventory management [9].

Today organizations are actively involved in the international programme Vision Zero ("Zero accident"). This digital technology is the main element, as without them the programme will not take place [10]. Vision Zero is a concept of zero injuries International social security Association (ISSA). Vision Zero - an organization of international level. The purpose of this movement is to reduce and eliminate fatal injuries in the workplace, to give industrial, environmental, fire safety, occupational safety a priority. The program solves the problem in the region as industrial safety and labor protection. In the framework of this program, smart digital technology will allow you to control the use by workers of personal protective equipment, provide video fixation of violations of requirements of industrial safety and labor protection, conduct pre-trip and pre-shift inspections to monitor the physiological state of the workers and their local location at the facilities. System software in this area has CROC is an integration platform that allows to provide safe work and increase productivity.

The digital platform connects to the public network in 3D-format event production process. It uses the following system of video analysis, local positioning, wearable and industrial Internet of things, control system and access control (ACS), Supervisory control and data acquisition (SCADA) and other processing information from a variety of sources, identifies hazards and risks, the information is transferred in a dispatch service or situational centre, developing ways of preventing and eliminating risks and hazards [11].

For example, the video Analytics system while fixing violations of the use of personal protective equipment, will signal to the monitoring centre (the "no face shield", "no ear"), i.e. determines the violation of requirements of labor protection. System allows with the help of "smart view" to identify violations dangerous actions of drivers, air traffic controllers, workers on the Assembly line. Video captures dangerous acts or omissions (distraction) workers and online sends information to the control centre (in Westminster).

The use of smart integration platform on the basis of legal regulation will improve the efficiency of observance of requirements of industrial safety and labor protection, to reduce the number of accidents, incidents and fatal accidents, to prevent theft, to develop and carry out prevention activities compliance with the requirements of all types of safety by identifying problem areas [12].

We have analysed the use of mobile applications in the field of industrial safety and labor protection, as one of the tools of the digital economy. Statistics says that on the screen of the smartphone we pay your attention, even in a production environment, every six minutes. On the use of mobile applications, spent most of your working time. Specialists in industrial safety and labor protection can communicate (communication) with each other and staff through the use of mobile applications. The mobile app will give the opportunity to lead and coordinate the work in the control systems of industrial safety and labor protection in the organization.

An example of such application can be a "BESAFE", developed by students of the Ural Federal 
University. The app is a modern and multifunctional assistant for specialist of industrial safety and labor protection. Importantly, it provides access to legal documents, maintains records of occupational injuries, including microtrauma, allows you to make plans for activities in the field of industrial safety and labor protection, to lead a panel of experts, answering questions of employees [13].

If the application will provide liaison with regulatory authorities, including the portion of scheduled and unscheduled inspections, his work will help improve the performance of the entire organization.

One of the main problems of the implementation of the tools of the digital economy in the field of industrial safety and labor protection remains the process of training. In UK with 1979 year works NEBOSH

National Examination Board of Occupational Safety and Health. The so-called national examination Board in occupational safety UK, which is the leading international organization for training and certification and certification of specialists on industrial safety and labor protection. Specialists who have mastered the study programme and passed the exams receive a certificate and become members of the Institute of occupational safety and health UK (Associate Member of the U.K. Institution of Occupational Safety and Health, IOSH).

International body NEBOSH organize the accreditation of training centres in different countries and on different continents, for training in its accredited courses. The process of exam covers only international organization NEBOSH in the UK, which ensures compliance with objectivity and impartiality. All courses are based on examples of best international practices in the field of industrial safety and labor protection [14].

In the Russian Federation, organizations with accreditation, implement a training program in only two courses:

"International General certificate NEBOSH in the field of labor protection";

"The introductory course NEBOSH in the field of labor protection in the workplace".

Training courses on industrial safety (industrial safety in the oil and gas industry, safety in construction) for the Russian Federation is not available. With a large number of joint oil and gas complex enterprises in the construction industry, the harmonization of standards on industrial safety and labor protection with the developed countries of the EU today, this training is a must. Analysing national and international system of training, we have established the lack of the necessary tools for modern organizations such as:

- Lack of tools, digital platforms for training specialists in the field of industrial safety and labor protection in Russia and in international organizations (in NEBOSH students write essays on the exam is strictly under the supervision of the teacher, translate it into English and sent for inspection to the UK, although with modern information support of this process can be simplified);

- The lack of legal regulation in the area of international training in the field of industrial safety and labor protection (training, examination, recognition of the appropriate certificate), including on digital platforms [15].

In providing training of staff in using digital tools and appropriate normative legal regulation the employer receives the following benefits:

- A high level of safety culture in organizations in which every employee is responsible for safety, participates in the process of identifying and addressing risks in the organization involved in the prevention of accidents and occupational diseases;

- A highly effective management system of industrial safety and labor protection in the organization, the basis of which will be the world's best practices in relevant areas;

- Social and economic benefits by improving employee health and saving money for losses from accidents, incidents, accidents and occupational diseases [16].

\section{RESULTS AND CONCLUSIONS}

The result of the research tools and legal regulation we have developed a distance learning course training "Digital technologies in industrial safety and labor protection", consisting of 8 modules:

1. Legislative and legal aspects of digitalization of industrial safety and labor protection.

2. Digital transformation of management systems of industrial safety and labor protection in the organizations (for example, associations for oil and gas).

3. Smart company - smart city. Tools for implementation of digital technology through human - oriented digital services for occupational safety.

4. Blockchain modules and platforms for industrial safety and labor protection.

5. Digital assistants in the work of a specialist on industrial safety and labor protection (mobile apps, voice assistants, digital service solutions security processes in the organization, etc.).

6. World experience of development of digital projects in the field of industrial safety and labor protection.

7. Augmented and virtual reality (forecasting and modelling of accidents, incidents, industrial accidents, technological emergencies.

8. Seminar on studied material. The scoring exercises. Obtaining the certificate of professional development. 
Upon completion of training a specialist in industrial safety and labor protection:

- Will receive a significant amount of knowledge in the field of digital economy and digital technologies;

- Expand the knowledge on possible use of digital technology in the field of industrial safety and labor protection;

- Get the skills of implementing modern digital technologies in industrial safety and labor protection into the business processes of the organization.

In the conditions of modern industrial production, increase of efficiency of systems of management of industrial safety and labor protection is possible only through the introduction of digital technologies under the following conditions:

- Providing legislative, legal, regulatory, technical and methodological foundations for the creation of interaction between the digital subsystems of industrial safety and labor protection in the organization and regulatory bodies - the Federal service for ecological, technological and nuclear supervision and Federal service for labor and employment;

- When implementing dashboards organizations on the websites of the Federal service for ecological, technological and nuclear supervision and Federal service for labor and employment and the full interaction information, including part of the audit of organizations and data Services (data exchange in certain digital formats);

- Establish the legal status of centres for training in establishing unified requirements for the use of common digital technologies in teaching and examination, including at the international level;

- The introduction of digital services, as analytical tools for safety in the organization (automated procedures for the issuance and use of personal protective equipment, investigation of accidents and occupational diseases prevention and technical investigation of accidents and incidents at hazardous production facilities, etc.).

\section{REFERENCES}

[1] V.N. Volkov, System analysis and information, DOE, 2016, 336 p.

[2] T.V. Gaibova, System analysis in engineering and technology, OSU, 2016, 222 p.

[3] M.V. Golovizina, Information technologies in Economics, INTUIT, 2016, 589 p.
[4] V.V. Baron, Information technology and business management, Vocational Education, 2017, 327 p.

[5] ROSTECHNADZOR (2020) Report on law enforcement compliance and enforcement activities by the Federal service for ecological, technological and nuclear supervision in the implementation of Federal state supervision in the field of industrial safety for the first months of 2019. http://www.gosnadzor.ru/public/law\%20enforce ment/ Accessed on 3 Dec 2020

[6] ROSTRUD (2018) A report on the activities of the Federal service for labor and employment for 2018. https://www.rostrud.ru/press_center/doklady/otchety-odeyatelnosti-federalnoy-sluzhby-po-trudu-i-zanyatosti/ Accessed on 3 Dec 2020

[7] I.V. Efremov, N.N. Rakhimov, Technogenic systems and environmental risk, OGU, 2016, 171 p.

[8] Yu.Yu. Gromov, Information technology, TSTU, 2015, 260 p.

[9] S.A. Sazonov, Information technology security GUS, 2015, 108 p.

[10] V.M. Kaziev, Introduction to the analysis, synthesis and modelling of systems, INTUIT, 2016, $270 \mathrm{p}$.

[11] E. Krylov (2017) Electronic evidence: when Skype, SMS and correspondence by e-mail will help to win an argument.

https://e.lawyercom.ru/article.aspx aid=540177 Accessed 23 Sep 2018

[12] S.A. Nesterov, Analysis and management of risks in information systems based on Microsoft operating systems, INTUIT, 2016, $250 \mathrm{p}$.

[13] Passport of the National Project National Program "Digital Economy of the Russian Federation" (approved by the Presidium of the Presidential Council for Strategic Development and National Projects under the President of the Russian Federation, Minutes No. 7 of June 4, 2019).

https://digital.gov.ru/uploaded/files/natsionalnayaprogra mma-tsifrovaya-ekonomika-

rossijskojfederatsii_NeN2nOO.pdf Accessed on 10 Dec 2020

[14] N. N. Rakhimov, Risk management, system analysis and modelling, OGU, 2016, 190 p. 
[15] N. Samara, Conditions and labor protection in modern Russia 4(3) (2017) 209-222. DOI: https://doi.org/10.18334/et.4.3.38310.

[16] J.I. Sedova, Legal Requirements in the transition to digital technology in the operation of hazardous production facilities, Perm legal almanac. Annual scientific journal 1 (2019) 128-137. 